principle of hit or miss, except perhaps in the gadget class of invention, is not applicable, and the complete inventor is a development of the scientific researcher". But to such a man, the suggestion that he would find it worth while studying Max Planck, Einstein and Eddington would come rather late, while that suggestion, even if accepted, would have no utility to the 'gadget' producer. The high hopes raised by the receipt of a treatise with the title "The Science of Invention" remain unfulfilled by Mr. Marshall's series. An authoritative examination of the position of invention in the modern State is still needed. In such an examination the commercial aspect may well prove to be insignificant, although research by one man or one set of workers may have to be restricted to the material inventions, leaving such things as modern systems of government, the most striking development of man's inventive faculty, to the historian or the alienist. From a calm investigation of the uses of material advances it may be found that they follow social changes and are called forth by them : but research is necessary to discover the vital facts of modern invention and, in Great Britain at any rate, there is little evidence that such research is being carried out. Is it fantastic to believe that if it is ever adequately made, we shall have general consent to the idea of complete control by the State of the inventive faculties of its members ?

\section{Viability of Plant Structures}

THE question of the length of the period of viability in seeds and other plant organisms is constantly cropping up, and, although a great deal has been written about it, there is still much to be discovered with regard to the actual length of time seeds and spores can remain viable. Reference was made to this problem in NATURE of May 2, 1931, p. 675, and an article on the subject was published in the Kew Bulletin of 1933,p. 257. In that article, all the cases of longevity that have been definitely authenticated were brought together. Possibly the oldest case is that of Nelumbo (the Japanese lotus) recorded by Ohga in the Botanical Magazine of Tokyo, 1923. Seeds of Nelumbo nucifera were found in a peat bed. buried under $2 \mathrm{ft}$. of loess in Southern Manchuria. The seeds all germinated and it is estimated that they were at least 120 years old and may have been as much as 400 years. It is well known, of course, that poppy seeds and charlock can retain their viability for very long periods, but for how long one cannot say definitely. According to an announcement in The Times of August 19, M. P. N. Kaptereff has succeeded in reviving plant organisms which have lain in the earth for thousands of years. It appears from this account that it is only spores which have shown signs of life, and it seems quite possible that spores of some of the lowly algæ could have survived in a frozen condition for a very long time. From the account it appears that blue-green algæ may be some of the plants which have developed - possibly some of the unicellular green algæ also. As to the grass-like plants which are mentioned, they might well have retained their general appearance in a frozen condition for a very long time, as the ice would preserve the form perfectly well. One would not expect them to have any life in them and this does not appear to have been the case.

\section{Native View of Baganda Institutions}

AN account by an African of his own institutions must normally, though not invariably, have an exceptional value for the ethnographer. Being as a rule a spontaneous production, it avoids the great danger of the usual method of inquiry, in which there is the risk of biasing the sources of information. Sir Apolo Kagwa, the Katikiro of Uganda, who produced in 1918 an account of Baganda history and institutions in his native language, was exceptionally well qualified for this undertaking. A man of considerable intellectual power, he had been associated with the royal household from his early youth, and when in 1897 the young Daudi Chwa, an infant, one year and six months old, was appointed king on the abdication and flight to German East Africa of his father, Mwanga, Apolo was made regent and prime minister. He thus had a personal and intimate knowledge of the critical times which led up to the intervention of the British forces in Uganda and the institution of a protectorate. His authority on State affairs and ritual is beyond question. One of the most valuable records he has preserved is that of the officers and queens of each ruler from the beginning of the line with the semi-legendary founder Kintu. The Rev. J. Roscoe, when collecting information for his book "The Baganda", derived a great deal of his material from the Katikiro ; and, in fact, Sir Apolo's book, which is an invaluable, and indeed a necessary, supplement to Roscoe, was written to expand and correct what he considered to be open to criticism in the work of the latter. The fact that Sir Apolo wrote in Luganda has proved a drawback; but this has now been remedied in a translation by Ernest B. Kalibala, edited by May Mandelbaum (Edel) (Columbia University Contributions to Anthropology, 22, 199. 4 dollars). For the convenience of students the mere repetitions of Roscoe's information are omitted, but references to "The Baganda" are given here as well as where Roscoe is supplemented or corrected.

\section{Safety in Mines Research}

As in past years, the Fourteenth Annual Report of the Safety in Mines Research Board includes a report of the Health Advisory Committee, which forms in fact Part 4 of the Report, the previous parts being Part 1, General ; Part 2, Instruction; and Part 3, Progress of Safety Researches. The Report, of course, begins with an expression of regret on the death of Dr. J. S. Haldane, who "had been a member of the Board since 1923" ; there is not a miner who will not re-echo the last sentence of the first paragraph in reference to Dr. Haldano- "His death is a severe loss to the whole mining community" ; whilst it also refers to the retirement of Prof. S. M. Dixon, who, as is well known, has rendered much valuable service in connexion with wire ropes used in mining. There is further a number of appendixes to the Report, one of which deals with protective equipment, and it is interesting to note that, generally 
speaking, protective equipment has been largely adopted by the miners themselves. It is worth knowing that Great Britain is not the only country adopting protective equipment, the article by Leprince-Ringuet on miners' hats appearing in the Annales des Mines of Paris proving this point. The various representatives of the local committees are doing good work in popularizing the use of protective equipment, and the subject of falls of ground is making fair progress, considering the inherent difficulties of the subject.

\section{Radio Relay Services}

RADro relay is much more common abroad, where it is regarded as a public service, than in Great Britain. In a pamphlet written by G. S. Lucas and E. S. Hall of the Research Department of the British Thomson-Houston Co., Ltd., a description is given of the radio relay equipment built and designed for the Midland Relay Services, Ltd. It is suitable for 300 subscribers but could easily be adapted to suit 1,000 or more subscribers. It has four radio receivers with their aerial equipment, and a short-wave receiver. The aerial equipment depends upon the locality and conditions of reception. For the installation carried out at Rugby, two vertical aerials about 25 feet in length are used for local reception. For long-distance work a horizontal aerial 100 feet long and 50 feet high is used. For use on short-wave reception a special $V$ doublet aerial has been installed. Two of the receivers are suitable for B.B.C. transmission and two for long-distance Continental programmes. The advantages offered to the public by this service are the replacement of aerials by simple overhead wires. The installation of only a simple speaker unit in the house is required; no power supply or battery is necessary. The main control station is under constant supervision and the receivers are adjusted for the best working conditions. The radio relay station is capable of relaying two or three independent programmes to all subscribers. All the vital points of the system are duplicated and the organization can deal quickly and effectively with faults and complaints as they arise.

\section{Telephone Development in Birmingham}

A LARGe and imposing building called Telephone House has been built in Birmingham to accommodate the telephone equipment for the city and also the Post Office and engineering and administrative staffs. A description of the telephone equipment required for the trunk, toll and central exchanges which were installed by Siemens Brothers and Co., Ltd., of Woolwich, to the order of the Post Office, is given in the September supplement of the Siemens Magazine. The introduction of the maximum fee of one shilling for three minutes on all inland trunk calls made after 7 o'clock in the evening has made the trunk service very popular, and the more recent introduction of a half-crown maximum for a three minute trunk call between any two places on the mainland of Great Britain will still further increase the amount of trunk traffic. Outside London, Birmingham is the most important telephone centre in Great Britain.
It is connected by direct trunk lines with all other zone centres and, in addition, forms an important link in the alternative trunk routes between London and other zone centres such as Liverpool, Manchester, Leeds, Sheffield, Nottingham and Leicester. The new trunk and toll equipment has been planned to meet the long distance (tr unk) and the short distance (toll) traffic anticipated in the Birmingham district during the next few years. Since 1930 the development of the trunk traffic has exceeded all expectations. There have been installed in the building 367 switchboards, and in addition a centralized manual board for the whole of the Birmingham area. In the same building also a 5,700 line full automatic equipment for the central exchange is being installed. Two motor generator sets driven from the 400 volt 3 phase 50 cycle public supply mains, with an output of 1,600 amperes at 57 volts, are being used.

\section{Research in Mental Diseases}

THe Annual Report, 1935-36, of the Joint Board of Research for Mental Disease of the City and University of Birmingham contains an account of much painstaking and laborious work (Birmingham : The University, 1936). The occurrence and distribution of 80 named varieties of micro-organisms are tabulated; 6,565 specimens were examined. Somewhat optimistically the report claims to have solved the problem of the cause of mental disease, since "it appears that mental disorder cannot be classed as an infectious disease, nor as a metabolic disorder, but that it is a clinical resultant of infectious and metabolic disorders acting during any period of the ante- and post-natal life of the individual, thus: determining the character and onset of the mental symptoms". Also, "The functional disturbances of the central nervous system responsible for the symptoms of mental disorder, can be clinically and pathologically associated with local disturbances of the vascular supply to certain vital centres of the brain". It is true that the pathology of some brain diseases that cause mental disorder is well established, for example, encephalitis, syphilis, tumours; but there still remains a host of disorders, ranging through hysteria and the anxiety and obsessional states to schizophrenic personalities, and cyclothymia. or manic-depressive conditions and paranoia, that have so far defied the laboratory expert.

\section{False Killer Whales in South Africa}

Dr. Leonard GILI, in the Report of the South African Museum for the year 1935 (1936, p. 10), recounts another of those mass strandings of Pseudorca crassidens which have become so frequent since the reappearance of the species in the Dornoch Firth. The school came ashore at Mamre, about fifty miles north of Cape Town, and the occurrence was peculiar because of the large number of whales stranded, about three hundred, and because they came ashore not on sand but on jagged rocks. But a common fcature of the strandings has been, as here, that the whales appear to have been trapped by a falling tide in channels cut off from the open sea by sand-banks. The Mamre stranding took place 